\title{
Unique Advantages of Public Art Education in Colleges and Universities in Inheriting Intangible Cultural Heritage
}

\author{
Pan Zhang \\ Jiangsu college of Engineering and Technology, Nantong, Jiangsu, 22600
}

Keywords: colleges and universities; public art education; intangible cultural heritage; integration; inheriting

\begin{abstract}
With the advancement of quality education, curriculums in colleges and universities are made up of public art education, whose roles in cultivating and promoting students' appreciation and aesthetics have been paid attention to. Intangible cultural heritage from ancestors, as precious treasures, need to be inherited and carried forward. There is a close connection between public art education and intangible cultural heritage development. Reform and innovation on public art education of colleges should be made on the basis of intangible cultural heritage development. Protecting and inheriting intangible cultural heritage need to be incorporated into public art education to realize sound and harmonious unity. This paper studies the situation of public art education and then puts forward some suggestions on heritage spread and education development in order to start a discussion.
\end{abstract}

\section{Introduction}

Public art education has been an important part of curriculums of colleges for advanced education in China. However, the reason why the importance fails to be attached to public art education in the entire teaching system is that colleges view it as a public teaching course. Reform needs to be carried on curriculums structure, teaching forms and practices urgently. Colleges should integrate intangible cultural heritage in a certain region in the process of public art education to establish one thinking that students are responsible for inheriting national culture in order to make them fond of our country, our nation and Chinese culture. Meanwhile, our country's intangible cultural heritage should be protected and inherited to maximize the teaching results of public art education.

\section{The Current Situation of Public Art Education in Colleges and Universities}

Public art education of colleges, as an important teaching content, plays a vital role in improving students' aesthetics. It can enrich their mental world, develop team consciousness and creative thinking and promote all-round development. Art education can strengthen students' aesthetics and enhance their self-cultivation and comprehensive qualities. For this, public art education of colleges cannot be replaced by any other curriculums.

Remarkable achievements have been made in accelerating institutionalization and standardization of public art education after issuing and implementing some regulations such as Art Education Rules and Public Consciousness Course Guidance Plan of National Common Colleges to further implement public art education.

When feeling happy about results from public art education, we should be clearly aware of the obvious problems. In view of the entire situation of public art education, related curriculums have been started, but little attention is paid to them. Lacking in professional teachers and teachers majoring in other areas are engaged in as a part-time job. In addition, the curriculum system of public art education is not reasonable enough. The content and form of teaching are relatively simple and backward. It only mechanically instills theoretical knowledge into students, ignoring the links of practice. Low enthusiasm and initiative have been found when having classes. If the purpose is to making up credits or just having fun, it is hard to achieve the original effect of art 
education.

\section{Protection and Inheriting of Regional Intangible Cultural Heritage}

In the arc of world's history development, China, as a country with long history standing in the eastern of world, has accumulated rich intangible cultural heritage. It is modernized nation with strong economy and comprehensive power of all time and the only one with uninterrupted culture. Intangible cultural heritages include art performance, traditional handicrafts, social manners, festivals and customs, which is closely connected to art. Intangible cultural heritage is defined by Notice on Strengthening Cultural Heritage Protection approved by the Stats Council in 2005 that intangible cultural heritage refers to various traditional cultural expressions that exist in immaterial form and are closely related to the life of the people and passed down from generation to generation, including oral narration, traditional performing arts, folk activities and ceremonies and festivals, and folks about nature and the universe. Traditional knowledge and practice, traditional handicraft skills and cultural spaces are associated with these traditional cultural expressions.

As our times develops and changes, it is common for people to be bound up in fast and modernized lifestyle. They have little understanding of intangible cultural heritage. If any changes fail to be taken in the situation, it is impossible for our next generation to experience a sense of national pride from outstanding intangible culture in one day. Protecting and inheriting our intangible cultural heritages can deepen understanding of intangible culture and is conducive to spreading excellent traditional culture to make Chinese culture prosperous in the world.

\section{Tips on Introducing Regional Intangible Cultural Heritage into Public Art Education}

Our intangible cultural heritage, a valuable education resources, not only enhances a sense of honor and pride for students but also gives play to art nurture and improve their aesthetics. Integration should be made between launching public art education and regional intangible cultural heritage to fully exert culture charm and improve the effect of art education.

\subsection{Establishing the education idea of inheriting intangible cultural heritage}

Public art education with strong profession and systematisms in our country mainly introduces some orthodox culture and art and has overlooked citing local intangible culture. Because intangible cultural heritage fails to be officially incorporated into course system, public art education is disconnected with intangible cultural development. Teachers majoring in public art need to build right educational ideas, be fully aware of educational values of intangible cultural heritage, gradually develop "cultural auto psyche, have good traditional culture to give play to modern values, enrich contents of public art education and establish organic unification between art education and culture inheriting.

Regional intangible cultural heritage with strong regionalism and pertinence has accumulated by life and work of local people. By organizing and refining regional intangible cultural heritage, excavating the artistic content and educational value, and integrating into the efficient art education curriculum system, a scientific curriculum system can be established to continue the spiritual connotation of intangible cultural heritage. Efficient public art education should be integrated with folk music, dance, arts and crafts, acrobatics, etc., and constantly expand its subject matter and content to attract more students' attention.

In terms of faculty, most of them graduated from normal art colleges and the teaching team are becoming younger. Mastering rich theorical knowledge related to art, they have little understanding of intangible cultural heritage. For this, it is difficult to integrate culture inheriting and art education. Targeted at the situation, colleges need to strengthen training for art teachers, have them master some knowledge about intangible cultural heritage, encourage them to deeply research topics on cultural heritage and improve teaching qualities and abilities to lay foundation for art education effect promotion. 


\subsection{Integrating class teaching with visiting practices}

Educational functions of intangible culture are mainly presented by its art carrier. If simply relying on teaching or viewing pictures or influences, we cannot obtain good artistic effects. Inheriting public art education and intangible cultural heritage in colleges must be off limits from classes, make students communicate with culture and art in close quarters, and provide necessary explanations to convey the national spirit and artistic thoughts contained in the heritage to the students. Some methods for students to appreciate art works should be taught. We should lead students to present novel ideas, cultivate and improve students' creative thinking. The author summarizes the following experiences in the practical teaching of integrating public art education and intangible cultural heritage.

1) Public art education, referred to as a teaching platform into intangible cultural heritage, should be incorporated into professional classes. With the rapid development of economy and society in China, the teaching platform must meet social requirements. Students should know that knowledge will be replaced instead of being abandoned. In contrast, inheriting and spreading the idea should be run through the whole process of public art education.

2) In the process of teaching, intangible cultural heritage protection center established in the school and a certain number of off-campus practice bases can be viewed as the basic elements of teaching, and actively implementing design practices, customs practice, holiday social practice and graduation internship, and leading students to conduct field trips. Only in this way folk arts and crafts can be widely spread in and out of the school.

3) Media and school periodicals can be served as a platform for academic communication and professional teaching. In line with the intangible cultural heritage window and columns related to public art education, there are theoretically valuable viewpoints and papers in order to assist the public art education in colleges and universities, thus improving the teaching effect of design and achieving the teaching purpose of design.

4) Students can be organized by teachers to visit local museums or come around some folk artists on holiday or weekend. They should also write down feelings and be encouraged to explore local cultural heritage.

\section{Conclusion}

According to the above research on public art education and regional intangible cultural heritage development, intangible cultural heritage, as a bright miracle of cultural treasure, is not only the cultural resources that we are proud of but also of great educational significance. Integration should be built between public art education and intangible cultural heritage, which enhances teaching effect and inherits and spreads good traditional culture. Colleges are fully aware of the importance of intangible cultural heritage and incorporate it into curriculums system. Meanwhile, a teaching staff with strong professional knowledge and business ability should be created to integrate class teaching and practice and promote the effects of art education.

\section{References}

[1] Liu Tongliang; Du Peng; Guo Fang. Analysis on Intangible Cultural Heritage Inheriting and University Public Art Education [J]. Theory Learning.2012 (11)

[2] Tian Zhongjuan. Research on Public Art Education of Colleges and Regional Intangible Cultural Heritage [J]. Journal of Lishui University.2014 (07)

[3] Zheng Yimo; Wang Yang. Role in Intangible Cultural Heritage Inheriting and Innovation from Art Education of colleges [J]. Journal of Hebei Normal University.2011 (08)

[4] Liu Fan; Pan Wenfang; He Xiaojuan; Deng Wei.Study on the Status Quo of Talents Training Model of Product Design Specialty in Undergraduate Colleges [J]. Design.2014 (12) 